\title{
PELATIHAN PEMBUATAN HAND SANITIZER ORGANIK BAGI MASYARAKAT DI KELURAHAN TANJUNG KRAMAT KECAMATAN HULONTHALANGI
}

\section{Training For The Making Of Organic Hand Sanitizers For Communities at Tanjung Kramat Village, Hulonthalangi District}

\author{
Ika Okhtora Angelia ${ }^{1}$, Desi Arisanti' ${ }^{2}$, Adnan Engelen ${ }^{3)}$ \\ Program Studi Teknologi Hasil Pertanian, Politeknik Gorontalo \\ Email : $\underline{\text { ikaokhtora@poligon.ac.id }{ }^{1)}}$
}

\begin{abstract}
ABSTRAK
Tujuan dari pengabdian ini adalah memberikan pelatihan dan pengetahuan dasar kepada masyarakat dalam pencegahan virus corona dan meningkatkan keterampilan masyarakat Tanjung Kramat dalam pembuatan hand sanitizer organik. Metode yang dilakukan dengan pemberian materi dalam bentuk audio visual menggunakan aplikasi zoom dirumah maisngmasing masyarakat yang menampilkan slide presentasi, demo pembuatan produk hand sanitizer organik instan. Adapun hasil yang didapatkan pada pelatihan ini adalah produk Hand Sanitizer Organik.
\end{abstract}

Kata Kunci: Pandemi; hand sanitizer; pelatihan; aplikasi zoom

\begin{abstract}
The aim of this service was to provide training and basic knowledge to the community in preventing the corona virus and improving the skills of the Tanjung Kramat community in making organic hand sanitizers. The method was conducted by providing material in the form of audio-visual using a zoom application in the homes of each community which displays presentation slides, demonstrations of making instant organic hand sanitizer products. The results obtained in this training are Organic Hand Sanitizer products.
\end{abstract}

Keywords: Pandemi; hand sanitizer; training; zoom application

\section{PENDAHULUAN}

Virus Covid-19 (virus Corona) yang menjadi pendemi di seluruh dunia saat ini mengajak kita lebih tanggap terhadap kebersihan diri dan lingkungan. Virus ini merupakan penyakit infeksi pernapasan akut yang disebabkan oleh coronavirus strain severe acute respiratorysyndrome coronavirus 2 (Beiu, Mihai, Popa, Cima dan Popescu, 2020). Salah satu tindakan yang dapat menghindarkan kita dari penularan virus Corona adalah dengan senantiasa menjaga kebersihan tangan kita. Berdasarkan informasi dari WHO mencuci tangan merupakan langkah dasar terhadap pencegahan penularan virus corona selain menggunakan masker.

Selain mencuci tangan dengan air dan sabun, penggunaan hand sanitizer juga dianjurkan, hal ini dilakukan bila kita sedang tidak di tempat yang tidak tersedia air maupun sabun. Penggunaan hand sanitizer dianggap sebagai salah satu metode sederhana, 
cepat, dan mudah untuk membersihkan tangan dari bakteri dan virus ketika sedang jauh dari tempat mencuci tangan. Pada umumnya terdapat dua jenis hand sanitizer yang dikenal oleh masyarakat yaitu yang mengandung alkohol dan non alkohol. Namun saat ini untuk hand sanitizer yang beralkohol sangat sulit dicari, kalau pun ada harganya sangat mahal dan sulit didapat oleh masyarakat biasa.

Virus Covid 19 saat ini sudah memasuki wilayah Gorontalo sehingga menimbulkan kecemasan dan ketakutan di masyarakat. Salah satu wilayah yang perlu diberikan perhatian dan pendampingan adalah Tanjung Kramat. Wilayah ini berada pada keringgian 0 - $50 \mathrm{mdpl}$ dan letaknya didekat Garis katulistiwa dan terletak antara 0 19' - 1 15' Lintang Utara dan 121 23' - 123 43' Bujur Timur. Mayoritas penduduk di Tanjung Kramat berprofesi sebagai nelayan dan pengrajin karawo. Secara umum kondisi rumah di wilayah ini saling berdekatan satu sama lainnya sehingga sangat dimungkinkan apabila ada yang terkena positif virus Corona akan mudah terinfeksi dengan cepat. Selain itu kendala akan keterbatasan pendidikan, pengetahuan dan keterampilan dalam pembuatan hand sanitizer khususnya tipe organik masih sangat minim.

Salah satu solusi yang bisa diberikan dari Dosen Program Studi Teknologi Hasil Pertanian Politeknik Gorontalo kepada masyarakat terkait meminimalkan terjadinya penularan virus Corona adalah memberikan pelatihan yang memanfaatkan tanaman sekitar rumah yaitu tanaman sereh dan daun sirih sebagai bahan hand sanitizer organik.

Pemilihan kedua tanaman ini dikarenakan tanaman ini mudah didapat dan memiliki khasiat yang tinggi dalam pencegahan terhadap penularan baik dari bakteri, jamur maupun virus. Pada kegiatan pengabdian ini masyarakat akan diajarkan membuat bahan hand sanitizer organik dalam bentuk instan. Pemilihan hand sanitizer organik instan diharapkan dapat disimpan dalam waktu lama dan praktis untuk digunakan sewaktu-waktu.

\section{Permasalahan Mitra}

Hasil diskusi antara tim pengabdian dan mitra, serta pengamatan langsung di lapangan. Terdapat beberapa permasalahan prioritas yang disepakati untuk diselesaikan bersama. Permasalah diantaranya yaitu;

1. Bagaimana cara memberikan pengetahuan dasar kepada masyarakat dalam pencegahan virus corona?

2. Bagaimana meningkatkan keterampilan masyarakat Tanjung Kramat dalam pembuatan hand sanitizer organik?

\section{SOLUSI DAN TARGET LUARAN}

\section{Solusi}

Adapun solusi dalam kegiatan pengabdian ini adalah memberikan pemahaman kepada masyarakat tentang bagaimana upaya pencegahan pendemik Covid-19 dengan cara memanfaatkan tanaman sereh dan daun sirih menjadi hand sanitizer instan.

Secara terperinci tujuan pelaksanaan kegiatan pelatihan ini adalah sebagai berikut:

1. Memberikan pengetahuan dasar kepada masyarakat Desa Tanjung Kramat dalam pencegahan virus corona?

2. Meningkatkan keterampilan masyarakat Desa Tanjung Kramat dalam pembuatan hand sanitizer organik?

\section{Luaran Yang Diharapkan}

Luaran yang diharapkan dari kegiatan ini adalah :
1. Produk berupa Hand Sanitizer Organik 
2. Publikasi di Jurnal Abdimas Gorontalo (JAG)

\section{METODE PELAKSANAAN}

Metode pelaksanaan dalam kegiatan ini adalah pemberian materi dalam bentuk audio visual by aplikasi zoom dirumah maisng-masing masyarakat yang menampilkan slide presentasi, demo pembuatan produk hand sanitizer organik instan.

Pengabdian Masyarakat ini akan dilaksanakan selama 1 hari (Senin 27 April 2020) via webinar zoom daring di Lab THP Politeknik Gorontalo.

\section{Alat dan bahan}

Alat

Alat-alat yang digunakan dalam pelatihan ini adalah: pisau, loyang, blender, oven, kompor gas, timbangan analitik.

\section{Bahan}

Bahan utama yang digunakan dalam pelatihan yaitu: daun sirih, minyak zaitun, lidah buaya, air.

Prosedur pembuatan hand sanitizer organik (untuk mendapatkan 50 botol ukuran $100 \mathrm{~mL}$ )

1. Di siapkan alat dan bahan yang akan digunakan.

2. Di cuci bersih 1000 gr daun sirih dengan air mengalir.

3. Keringkan lalu dipotong sampai berbentuk kecil-kecil

4. Rebus 5 Liter air hingga mendidih, lalu rendam 1000 gr daun sirih yang telah dipotong-potong

5. Ambil panci lalu lakukan proses steam pada air yang telah dicampur dengan 1000 gram daun sirih

6. Steam menggunakan api kecil selama 30 menit lalu saring

7. Hasil saringan merupakan ekstrak daun sirih yang dapat digunakan sebagai pengganti etanol yang ada di hand sanitizer

8. Tambahkan $200 \mathrm{ml}$ ekstrak lidah buaya sebagai moisturizer lalu aduk rata dan tambahkan air agar hand sanitizer tidak berwarna

9. Masukkan ke dalam botol semprot ukuran $100 \mathrm{ml}$

10. Siap digunakan

\section{HASIL PELAKSANAAN KEGIATAN}

Program Pengabdian Kepada Masyarakat tahun ini berbeda dengan pelaksaan kegiatan sebelumnya, hal ini dikarenakan virus Corona sudah mewabahi hampir di semua tempat dan semua usia. Sehingga tidak memungkinkan kegiatan ini dilaksanakan dengan bertatap muka secara langsung. Memanfaatkan teknologi informasi yang saat ini sedang populer merupakan salah satu kemudahan untuk mentransfer ilmu dengan aman dan cepat. Oleh karenanya tim pelaksanaan kegiatan pengabdian secara daring menggunakan APP Zoom yang di download di hp masing-masing.

Tim pengabdian ini terdiri dari tiga orang dosen yang berasal dari Program Studi Teknologi Hasil Pertanian. Untuk pelaksanaan kegiatan dilaksanakan di Laboratorium Teknologi Hasil Pertanian Politeknik Gorontalo. Ada beberapa tahap pelaksanaan kegiatan yaitu: tahap persiapan izin kegiatan kepada daerah yang menjadi tujuan objek kegiatan, persiapan bahan dan alat, pemberian materi secara daring melalui presentasi slide power point via Webinar APP Zoom, praktek pembuatan hand sanitizer organik dan dilajutkan dengan diskusi dan tanya jawab.

Hasil dari pelaksanaan kegiatan ini dapat dilihat dari respon timbal balik dari diskusi yang berlangsung cukup baik. Setelah pemberian materi dan kegiatan praktek langsung timbul beberapa pertanyaan kepada tim pelaksana kegiatan 
dan direspon dengan jawaban yang dapat dimengerti oleh masyarakarat di Desa Tanjung Keramat. Pemilihan Desa Tanjung Keramat sebagai tempat tujuan pelaksanaan kegiatan karena masyarakatnya sudah tidak asing lagi dengan penggunaan APP Zoom di HP. Hal ini tidak terlepas dari peran Kepala Desa atau biasa disebut dengan Ayahanda yang sudah berhasil mencerdaskan masyarakatnya dengan memanfaatkan Teknologi Informasi. Meningkatnya pengetahuan masyarakat untuk lebih menjaga diri dan lingkungan dengan memanfaatkan tumbuhan yang ada disekitar pekarangan yaitu daun sirih dan lidah buaya agar dijadikan hand sanitizer organik yang mudah, murah serta efektif merupakan tujuan utama dari kegiatan ini.

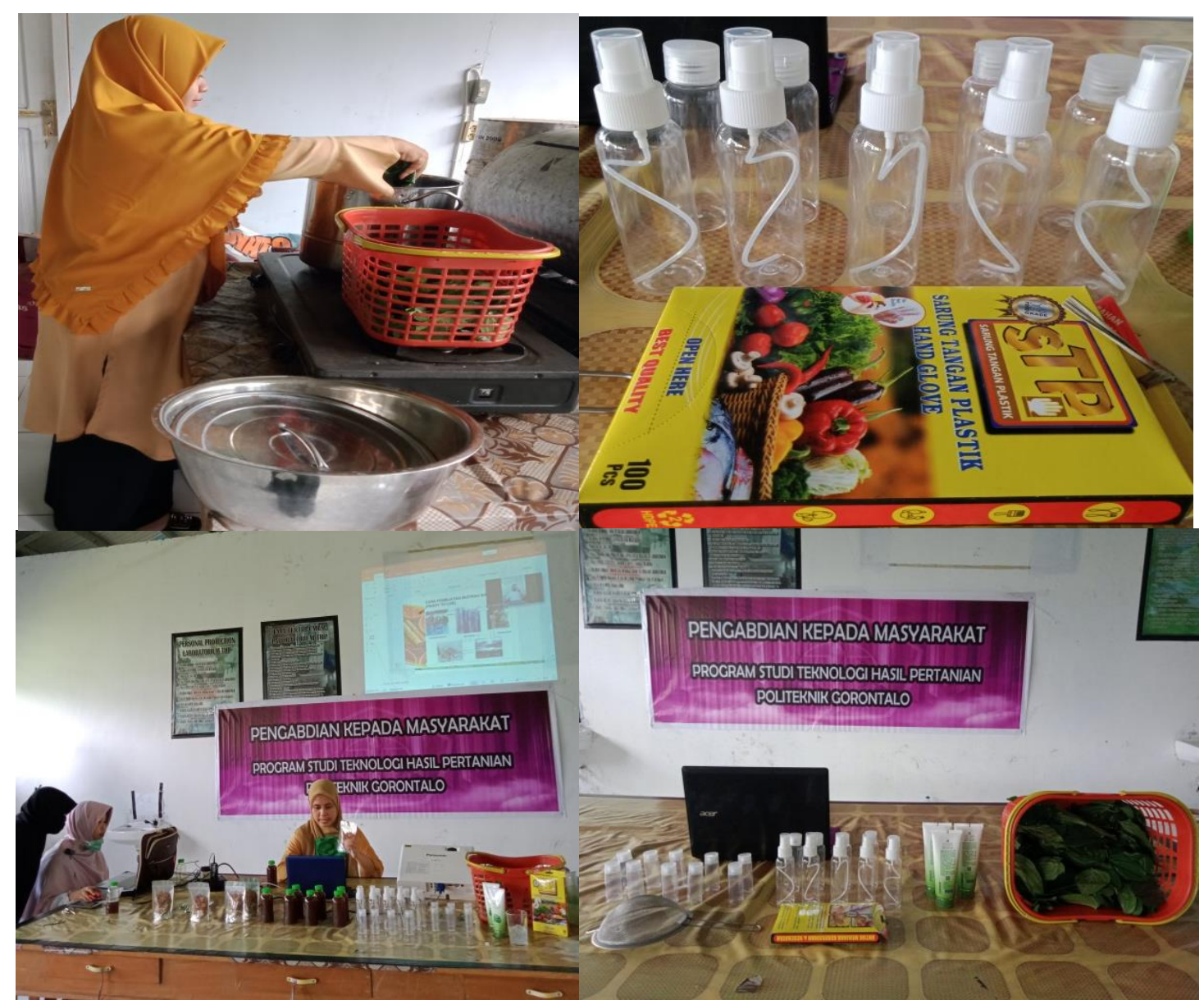

Gambar 1. Proses pembuatan hand sanitizer berbahan organik

Tidak hanya sampai di proses pembuatan saja, kami tim pengabdian juga mendistribusikan hasil praktek pembuatan hand sanitizer organik kepada masyarakat Desa Tanjung Keramat. Proses pembagiannya pun mengikuti prototipe kesehatan dengan menghindari kerumunan secara masal agar dapat terhindar dari peningkatan Covid-19. Hal ini sesuai dengan pendapat Meri dkk, 2020 bahwa hand sanitizer dan masker berfungsi sebagai upaya preventif bagi masyarakat terhadap peningkatan kasus Covid-19 ini. Teknis pembagiannya yaitu mendatangi tempat yang menjadi tujuan hingga semua 
produk berhasil didistribusikan hingga habis.

Tahap akhir dari kegiaatan ini adalah melakukan evaluasi dan pemantauan sejauh mana masyarakat Desa Tanjung Keramat terus mempraktekan secara mandiri pembuatan hand sanitizer organik tesebut. Penggunaan dan pembuatan hand sanitizer ini adalah salah satu usaha sosialisasi yang dilakukan agar menambah pengetahuan warga masyarakat terahdap bahaya penyebaran Covid-19. Hal ini sesuai dengan pendapat kurniawati dkk (2020) yang menyatakan bahwa sosialisasi hidup bersih untuk mengantisipasi penyebaran virus adalah dengan cuci tangan. Proses pemantauan diketahui dari informasi yang diberikan oleh kepala desa atau ayahanda Desa Tanjung Keramat yang menyatakan bahwa masyarakatnya terus memperoduksi secara mandiri hand sanitizer organik tersebut di rumah masing-masing .

\section{KESIMPULAN DAN SARAN}

Kesimpulan pada pengabdian masyarakat yang telah dilakukan oleh tim Politeknik Gorontalo adalah hand sanitizer berbahan organik dapatdigunakan oleh masyarakat Desa Tanjung sebagai protokol kesehatan selama masa pandemik.

Saran pada pengabdian masyarakat ini adalah pembuatan hand sanitizer dapat menggunakan bahan-bahan organik lain yang masih banyak di sekitar lingkunga.

\section{DAFTAR PUSTAKA}

Beiu, C., Mihai, M., Popa, L., Cima, L., and Popescu, M.N. 2020. Frequent hand washing for Covid-19 prevention can cause handdarmatitis: management tips from frequent hand washing to hand dermatis. Cureus 12(4). https://doi.org/10.7759/cureus.75 06.

Meri, M., Khusnul, K., Suharti, R., Mardiana, U., dan Nurpalah, R. Pemberdayaan masyarakat dalam penggunaan hand sanitizer dan masker sebagai upaya preventif terhadap Covid-19. Bantenese Jurnal Pengabdian Masyarakat, 2(1):26-33.

Kurniawati, K.R.A., Santosa, F.H.S., dan Bahri Samsul. 2020. Sosialisasi hidup di tengah wabah virus corona. JPMB, 3(1):58-65. 